\title{
Optimization of Promethazine and Demethylpromethazine Separation Conditions in Capillary Electrophoresis by Response Surface Methodology
}

\author{
Chunxiu Gu ${ }^{1,2}$, BingHan ${ }^{1}$, Yan Dong ${ }^{1, *}$, Baining Liu ${ }^{1,2, *}$, Kaowen Zhou ${ }^{1,2, *}$ \\ ${ }^{1}$ Biochemical Engineering College, Beijing Union University, Beijing 100023, China \\ ${ }^{2}$ Beijing Key Laboratory of Biomass Waste Resource Utilization, Beijing 100023, China \\ *E-mail: zhoukaowen@buu.edu.cn, dongyan@buu.edu.cn, liubaining@buu.edu.cn
}

doi: $10.20964 / 2021.03 .36$

Received: 11 November 2020/ Accepted: 2 January 2021 / Published: 31 January 2021

\begin{abstract}
Demethylpromethazine (DMPMZ) is one of the main metabolites of promethazine (PMZ). DMPMZ has only one methyl less than PMZ. In the past, in order to separate them by capillary electrophoresis (CE), it is often necessary to add additives to separation buffer solution. Under the optimized experimental conditions by response surface methodology, however, PMZ and DMPMZ can be separated well without using additives. The optimum CE conditions were $21.846 \mathrm{mmol} / \mathrm{L}$ phosphate buffer solution ( $\mathrm{pH}$ 5.653) and separation voltage of $14.408 \mathrm{kV}$. The resolution of PMZ and DMPMZ is more than 1.5 without any additives under the optimized experimental conditions. The optimization method is universal for many multiparameter processes.
\end{abstract}

Keywords: Capillary electrophoresis; Promethazine; Demethylpromethazine; Optimization; Response surface methodology

\section{$\underline{\text { FULL TEXT }}$}

(C) 2021 The Authors. Published by ESG (www.electrochemsci.org). This article is an open access article distributed under the terms and conditions of the Creative Commons Attribution license (http://creativecommons.org/licenses/by/4.0/). 